\title{
Requirement for BDNF in the Reconsolidation of Fear Extinction
}

\author{
Andressa Radiske, ${ }^{1}$ Janine I. Rossato, ${ }^{1}$ Cristiano A. Köhler, ${ }^{1}$ Maria Carolina Gonzalez, ${ }^{1}$ Jorge H. Medina, ${ }^{1,2}$ \\ and Martín Cammarota ${ }^{1}$ \\ ${ }^{1}$ Memory Research Laboratory, Brain Institute, Federal University of Rio Grande do Norte, RN 59056-450, Natal, Brazil, and ${ }^{2}$ Laboratory for Memory \\ Research, Institute for Cell Biology, School of Medical Sciences, University of Buenos Aires, CP 1121, Buenos Aires, Argentina
}

\begin{abstract}
Therapies based on the impairment of reconsolidation or the enhancement of extinction offer the possibility of decreasing the persistent recollection of distressing memories. However, the direct interplay between reconsolidation and extinction has rarely been considered. Previously, we reported that reactivation induces reconsolidation of fear extinction memory. Here, using a step-down inhibitory avoidance learning paradigm in rats, we show that intrahippocampus infusion of function-blocking anti-BDNF antibody immediately or $6 \mathrm{~h}$ after extinction memory reactivation impairs the reconsolidation of extinction. Extinction memory reactivation increases ${ }_{\text {pDNF, }}$ BDNF, and tropomyosin receptor kinase B (TrkB) phosphorylation levels in dorsal CA1, while blocking BDNF maturation in the hippocampus with plasminogen activator inhibitor 1 hinders the persistence of extinction and induces the recurrence of fear. Moreover, coinfusion of recombinant BDNF $(0.25 \mu \mathrm{g} / \mathrm{side})$ after extinction memory reactivation impedes the recovery of the avoidance response induced by inhibiting gene expression and protein synthesis in the dorsal hippocampus. Our findings unravel a new role for BDNF, suggesting that this neurotrophin is necessary and sufficient to maintain the reactivated fear extinction engram.
\end{abstract}

Key words: BDNF; extinction; hippocampus; learning; memory; reconsolidation

\section{Introduction}

Repeated unreinforced reexposure to the conditioned stimulus induces extinction of conditioned fear. This protein synthesisdependent process creates an inhibitory memory that competes with, but does not destroy, the original one. Instead, brief reexposure to the conditioned stimulus results in reconsolidation of the learned response. Reconsolidation restabilizes the trace labilized during unreinforced retrieval and, depending on the conditions prevailing at that moment, can also strengthen or update the reactivated memory engram. Blockade of memory reconsolidation and enhancement of extinction learning offer the therapeutic possibility of diminishing the impact caused by the intrusive recollection of traumatic events (Parsons and Ressler, 2013). However, the direct interplay between reconsolidation and extinction has seldom been analyzed. Previously, we demon-

\footnotetext{
Received Oct. 3, 2014; revised March 19, 2015; accepted March 20, 2015.

Author contributions: A.R., J.I.R., C.A.K., and M.C. designed research; A.R., J.I.R., C.A.K., and M.C.G. performed research; A.R., J.I.R., C.A.K., M.C.G., J.H.M., and M.C. analyzed data; A.R., C.A.K., M.C.G., and M.C. wrote the paper.

This work was supported by Conselho Nacional de Desenvolvimento Científico e Tecnológico (CNPq), Coordenação de Aperfeiçoamento de Pessoal de Nível Superior (CAPES), and Fundação de Amparo à Pesquisa do Estado do Rio Grande do Sul (FAPERGS) to M.C. A.R. holds a FAPERGS PhD Research Fellowship through Programa de Pós-Graduação em Gerontologia Biomédica at Pontifícia Universidade Católica do Rio Grande do Sul. C.A.K. is a Postdoctoral Research Fellow supported by CAPES. M.C.G. holds a Young Talents Attraction Postdoctoral Research Fellowship through CAPES. J.H.M. is a Visiting Researcher Fellow supported by CNPq through the Science without Borders Program.

The authors declare no competing financial interests.

Correspondence should be addressed to Dr. Martín Cammarota, Memory Research Laboratory, Brain Institute, Federal University of Rio Grande do Norte, Av. Nascimento de Castro 2155, RN 59056-450, Natal, Brazil. E-mail: martin.cammarota@neuro.ufrn.br.

DOI:10.1523/JNEUROSCI.4093-14.2015

Copyright $\odot 2015$ the authors $\quad 0270-6474 / 15 / 356570-05 \$ 15.00 / 0$
}

strated that fear extinction memory can undergo protein synthesis-dependent reconsolidation in the hippocampus (Rossato et al., 2010). This suggests that maintenance of fear extinction memory can be modulated upon its reactivation, and indicates that understanding the molecular bases of extinction memory reconsolidation can lead to pharmacological strategies for increasing the persistence of extinction and therefore help post-traumatic stress disorder patients to overcome the recurrence of disturbing recollections.

BDNF is a key member of the neurotrophic family of signaling proteins. In addition to its well-documented participation in neuronal proliferation and survival, BDNF regulates synaptic plasticity and memory storage and is linked to fear extinction (Bekinschtein et al., 2008a; Panja and Bramham, 2014; RosasVidal et al., 2014). Intrahippocampus administration of BDNF induces extinction of conditioned fear even in the absence of extinction training (Peters et al., 2010) and rescues the late-phase of long-term potentiation as well as the amnesia caused by protein synthesis inhibitors (Pang et al., 2004; Bekinschtein et al., 2008b). Actually, hippocampus-specific deletion of BDNF impairs aversive memory extinction (Heldt et al., 2007). Therefore, we posited that BDNF is also responsible for sustaining avoidance extinction after reactivation. If this hypothesis is true, then impairing BDNF function upon reactivation of extinction memory should recover the learned fear response. Furthermore, when administered at the moment of fear extinction reactivation, exogenous BDNF should suffice to prevent the reappearance of fear caused by blocking extinction memory reconsolidation. 

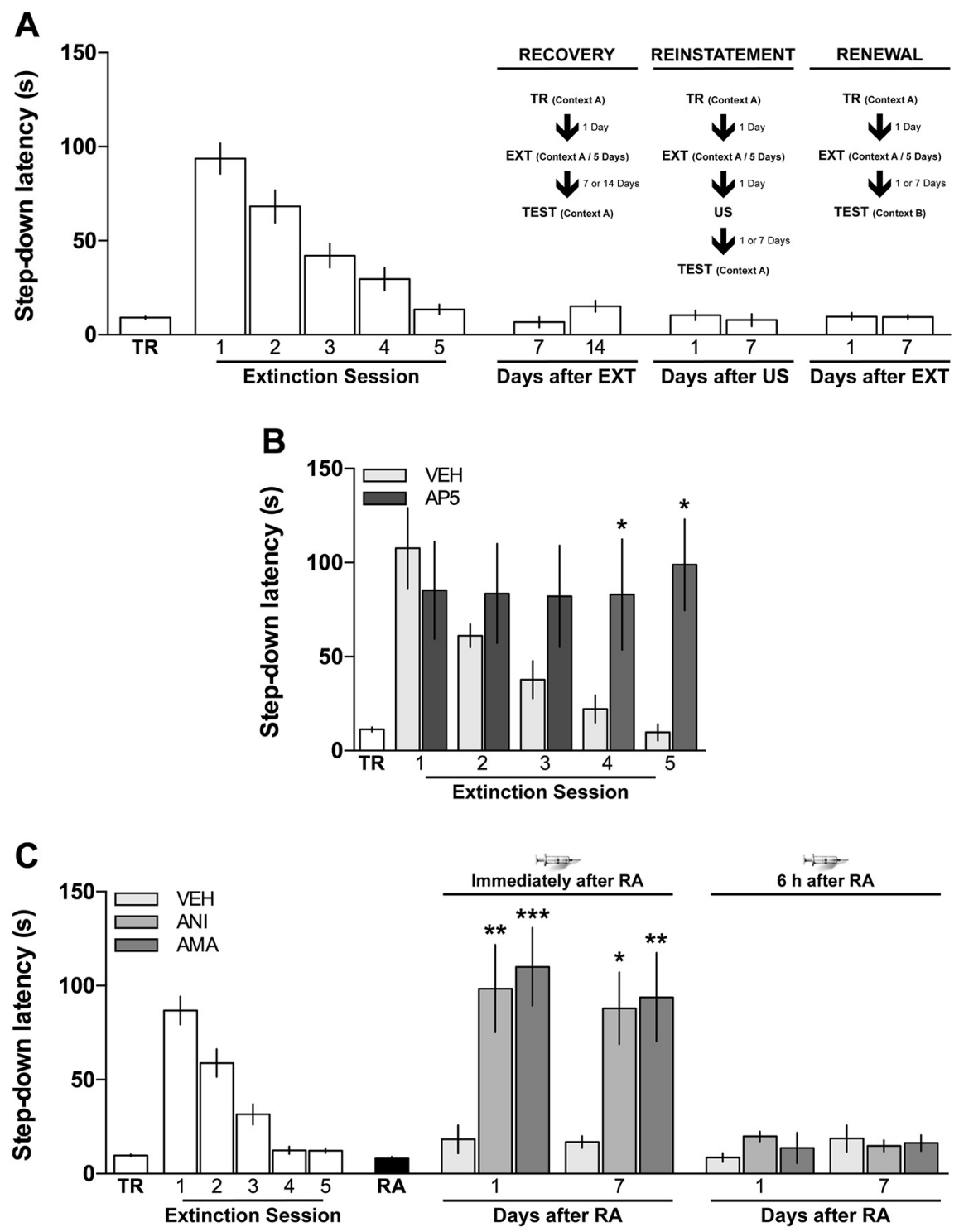

Figure 1. Retrieval induces reconsolidation of fear extinction memory. $A$, Extinction of inhibitory avoidance memory is not prone to spontaneous recovery, reinstatement, or renewal, and requires NMDAr activation in the dorsal hippocampus. Animals were trained in IA (TR) and, beginning $24 \mathrm{~h}$ later, were submitted to one daily extinction session (EXT) in the training context (Context A) for $5 \mathrm{~d}$. After that, the animals were randomly assigned to one of three different experimental groups. The first group (Recovery) was tested for retention in Context A 7 or $14 \mathrm{~d}$ after the last extinction session. The animals in the second group (Reinstatement) received a noncontingent footshock (US) identical in intensity and duration to that received during IA training, but in a different context, $24 \mathrm{~h}$ after extinction, and were tested for retention in Context $\mathrm{1}$ or $7 \mathrm{~d}$ later. The animals in the third group (Renewal) were treated as the animals in the Recovery Group but were tested for retention in Context B. $\boldsymbol{B}$, Animals trained in IA were submitted to one daily extinction session in the training context for $5 \mathrm{~d}$ (first session $24 \mathrm{~h}$ after IA training). Immediately after each session, the animals received bilateral intra-CA1 microinfusions of vehicle (VEH = $0.1 \%$ DMSO in saline) or AP5 (5 $\mu \mathrm{g} /$ side). Data are expressed as mean \pm SEM. $n=7$ per group. ${ }^{*} p<0.05$ (Holm-Sidak's multiplecomparison test after two-way repeated-measures ANOVA).C, Inhibition of gene expression or protein synthesis in dorsal CA1 immediately afterfear extinction memory reactivation recovers the learned fear response. Animals were trained in IA (TR) and, beginning $24 \mathrm{~h} \mathrm{later}$, were submitted to one daily extinction session for $5 \mathrm{~d}$. Twenty-four hours after the last extinction session, extinction memory was reactivated (RA) and, immediately or $6 \mathrm{~h}$ later, the animals received bilateral intra-CA1 microinfusions of vehicle (VEH $=0.1 \%$ DMSO in saline), the protein synthesis inhibitor ANI (160 $\mu \mathrm{g} /$ side), or the mRNA synthesis blocker AMA ( $45 \mathrm{ng} / \mathrm{side}$ ). Retention was assessed 1 or $7 \mathrm{~d}$ after RA. Data are expressed as mean \pm SEM. $n=8-12$ per group. ${ }^{*} p<0.05$ (Dunnett's multiple-comparison test after ANOVA). ${ }^{* *} p<0.01$ (Dunnett's multiple-comparison test after ANOVA). ${ }^{* * *} p<0.001$ (Dunnett's multiple-comparison test after ANOVA).

\section{Materials and Methods}

Subjects, surgery, and drug infusion procedures. The subjects were experimentally naive 3-month-old male Wistar rats, weighting 280-310 g at the start of the experiments. They were housed in groups of 5 , kept with free access to water and food in a holding room maintained at $22^{\circ} \mathrm{C}-23^{\circ} \mathrm{C}$ on a normal light cycle (12 h light:12 h dark; lights on at 6.00 A.M.), and implanted with 22-gauge guides aimed to the CA1 region of the dorsal hippocampus at stereotaxic coordinates: anteroposterior, -4.2 ; laterolateral, \pm 3.0 ; dorsoventral, -3.0 . The animals were allowed to recover from surgery for $4 \mathrm{~d}$ before any other procedure. At the time of drug delivery, infusion cannulas were tightly fitted into the guides and injections $(1 \mu \mathrm{l} /$ side $)$ performed over $60 \mathrm{~s}$ with a microinjection pump. The cannulas were left in place for 60 additional seconds to minimize backflow. At the end of surgery, animals were injected with a single dose of meloxicam $(0.2 \mathrm{mg} / \mathrm{kg})$ as analgesic. Behavioral procedures commenced 5-7 $\mathrm{d}$ after surgery. The placement of the cannulas was verified postmortem: $2-4 \mathrm{~h}$ after the last behavioral test, $1 \mu \mathrm{l}$ of a $4 \%$ methylene-blue was infused as described above and the extension of the dye 30 min thereafter taken as an indication of the presumable diffusion of the previously given drug. Only data from animals with correct implants were analyzed.

Inhibitory avoidance (IA) training. After recovery from surgery, animals were handled once a day for $2 \mathrm{~d}$ and then trained in the onetrial step-down IA task during the light phase of the subjective day (between 9:00 A.M. and 11:00 A.M.). The training apparatus was a $50 \times$ $25 \times 25 \mathrm{~cm}$ Plexiglas box with a $5 \mathrm{~cm}$-high, 8 -cm-wide, and $25-\mathrm{cm}$-long platform on the left end of a series of bronze bars that made up the floor of the box. For training, animals were placed on the platform facing the left rear corner of the training box and, when they stepped down and placed their four paws on the grid, received a $2 \mathrm{~s} 0.5 \mathrm{~mA}$ scrambled footshock and were immediately withdrawn from the training box.

IA memory extinction procedure. To extinguish the learned avoidance response, rats trained in IA were submitted to 5 unreinforced test sessions $24 \mathrm{~h}$ apart. For this purpose, the animals were put back on the training box platform until they stepped down to the grid. No footshock was given, and the animals were allowed to explore the training apparatus freely for $30 \mathrm{~s}$ after they had stepped down. During this time, the animals stepped up onto the platform and down again several times. To reactivate the extinction memory trace, $24 \mathrm{~h}$ after the last extinction training session, the animals were put on the training box platform until they stepped down and, right after that, were removed from the training box. In some experiments, the animals were submitted to a second extinction protocol after memory reactivation.

Drugs. Anisomycin (ANI; $160 \mu \mathrm{g} /$ side, Sigma-Aldrich), $\alpha$-amanitin (AMA; 45 ng/ side, Sigma-Aldrich), AP5 (5 $\mu \mathrm{g} / \mathrm{side}$, SigmaAldrich), and plasminogen activator inhibitor 1 (PAI-1; 50 ng/side, Sigma-Aldrich) were dissolved according to the manufacturer's instructions and stored protected from light at $-20^{\circ} \mathrm{C}$ until use. Right before that, an aliquot was thawed and diluted to working concentration in $0.1 \%$ DMSO in saline, $\mathrm{pH}$ 7.2. The doses used were determined based on pilot experiments and previous studies showing the behavioral and biochemical effects of each compound (Bekinschtein et al., 2007; Revest et al., 2014). Human recombinant BDNF was 
from Sigma-Aldrich (lot \#SLBC5725V), and function-blocking anti-BDNF antibody (BDNFab) was from EMD Millipore. They were dissolved at working concentration in sterile saline and stored at $-20^{\circ} \mathrm{C}$ until use. BDNF was administered at $0.25 \mu \mathrm{g} / \mathrm{side}$, a dose that has been previously shown to reverse the amnesic effect caused by inhibition of hippocampal protein synthesis (Bekinschtein et al., 2008b). BDNFab was administered at $0.5 \mu \mathrm{g} /$ side, a dose that has been previously shown to hinder BDNF signaling in the dorsal hippocampus (Bekinschtein et al., 2007).

Immunoblotting. Animals were killed by decapitation and the CA1 region of the dorsal hippocampus rapidly dissected out and homogenized in ice-chilled homogenization buffer (20 mm Tris-HCl, pH 7.4, containing 0.32 M sucrose, 1 mм EDTA, 1 mм EGTA, $1 \mathrm{~mm}$ PMSF, $10 \mu \mathrm{g} / \mathrm{ml}$ aprotinin, $15 \mu \mathrm{g} / \mathrm{ml}$ leupeptin, $10 \mu \mathrm{g} / \mathrm{ml}$ bacitracin, $10 \mu \mathrm{g} / \mathrm{ml}$ pepstatin, $50 \mathrm{~mm} \mathrm{NaF}$, and $1 \mathrm{~mm}$ sodium orthovanadate). Protein concentration was determined using the BCA protein assay (Pierce), and equal amounts of proteins fractionated by SDSPAGE before being transferred to PVDF membranes (Immobilon-P, Millipore). After verification of protein loading by Ponceau $S$ staining, the blots were blocked in Tween Tris$\mathrm{HCl}$ buffer saline (TTBS; $100 \mathrm{~mm}$ Tris- $\mathrm{HCl}$, $\mathrm{pH} 7.5$, containing $0.9 \% \mathrm{NaCl}$ and $0.1 \%$ Tween $20)$ and incubated overnight with anti-BDNF (1:5000 dilution, Santa Cruz Biotechnology), anti- ${ }_{\text {pro }}$ BDNF (1:5000 dilution, SigmaAldrich), anti-tropomyosin receptor kinase B (TrkB) (1:5000 dilution, Sigma-Aldrich), antipTyr515TrkB (1:10,000 dilution, SigmaAldrich), or $\beta$-tubulin (1:20,000, Abcam). The blots were washed in TTBS and incubated with HRP-coupled anti-IgG antibody, washed again, and the immunoreactivity detected using the West-Pico enhanced chemiluminescence kit (Pierce). Densitometric analyses were performed with an ImageQuant RT-ECL system (GE Healthcare).

\section{Results}

To test the hypotheses mentioned above, we used a one-trial step-down IA task in rats. IA training produces a persistent hippocampus-dependent aversive memory (Bekinschtein et al., 2008 b). However, repeated reexposure to the training apparatus in the absence of the ensuing footshock induces the NMDArdependent extinction of the IA response $\left(F_{(1,12)}=4.77, p=0.04\right.$ for treatment and $F_{(4,48)}=2.69, p=0.04$ for treatment $\times$ session interaction), which is not prone to spontaneous recovery, reinstatement, or renewal (Fig. $1 A, B$ ). Confirming and extending previous results (Rossato et al., 2010), we found that the protein synthesis inhibitor ANI (160 $\mu \mathrm{g} / \mathrm{side})$ and the mRNA synthesis blocker AMA (45 ng/side) impaired the retention of extinction when given in the dorsal hippocampus immediately after extinction memory reactivation $\left(F_{(2,27)}=9.64, p=0.0007\right.$ and $F_{(2,27)}=$ 7.47, $p=0.0026$ for 1 and $7 \mathrm{~d}$ after reactivation, respectively) but not $6 \mathrm{~h}$ thereafter (Fig. $1 C$ ), indicating that reconsolidation of avoidance extinction requires not only protein synthesis but also gene expression in the hippocampus. We also found that intradorsal hippocampus infusion of BDNFab $(0.5 \mu \mathrm{g} / \mathrm{side})$ immediately (Fig. $2 A ; t_{(22)}=5.19$ and $t_{(22)}=4.79 ; p<0.0001$ for 1 and $7 \mathrm{~d}$, respectively) or $6 \mathrm{~h}$ after extinction memory reactivation (Fig.
$2 A ; t_{(19)}=6.01$ and $t_{19}=4.65 ; p<0.0001$ for 1 and $7 \mathrm{~d}$, respectively) induced the reappearance of the IA response on test sessions performed 1 or $7 \mathrm{~d}$ later. BDNFab had no effect on extinction memory persistence when given $12 \mathrm{~h}$ after reactivation or when injected $24 \mathrm{~h}$ after the last extinction training trial in the absence of a behaviorally relevant event, indicating that it did not alter locomotion, motivation, or anxiety or affected the functionality of the hippocampus nonspecifically. The mnemonic effect of BDNFab cannot be attributed to transient inhibition of extinction memory expression either, because reextinction of the recovered avoidance response necessitated several reexposure sessions and was blocked by the NMDAr antagonist AP5 $(5 \mu \mathrm{g} /$ side) (Fig. $2 B ; F_{(1,20)}=10.41, p=0.004$ for treatment and $F_{(4,80)}$ $=4.39, p=0.003$ for treatment $\times$ session interaction $)$, exactly as initial extinction. Extinction memory reactivation increased pro BDNF and BDNF levels, as well as the phosphorylation of TrkB at Tyr 515 (pTrkB) in dorsal CA1, but had no effect on total TrkB expression (Fig. $3 A$ ). pro BDNF peaked $30 \mathrm{~min}$ after reactivation and remained increased for at least $90 \min \left(F_{(5,20)}=7.02, p=\right.$ $0.0006)$. The increases in $\operatorname{BDNF}\left(F_{(5,20)}=5.01, p=0.0039\right)$ and pTrkB levels $\left(F_{(5,20)}=5.30, p=0.0029\right)$ were slower and reached a maximum between $180 \mathrm{~min}$ and $360 \mathrm{~min}$ after reactivation, probably reflecting the proteolytic conversion of newly synthesized pro BDNF to mature BDNF, a key step in BDNF signaling and memory processing. Indeed, intradorsal hippocampus infusion of the BDNF maturation blocker PAI-1 (50 ng/side) (Revest et al., 2014) immediately after extinction memory reactivation also hampered the persistence of extinction and induced the reap- 
A
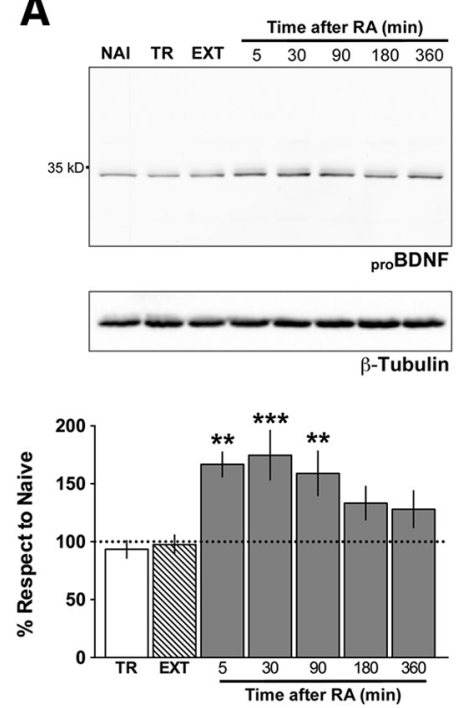
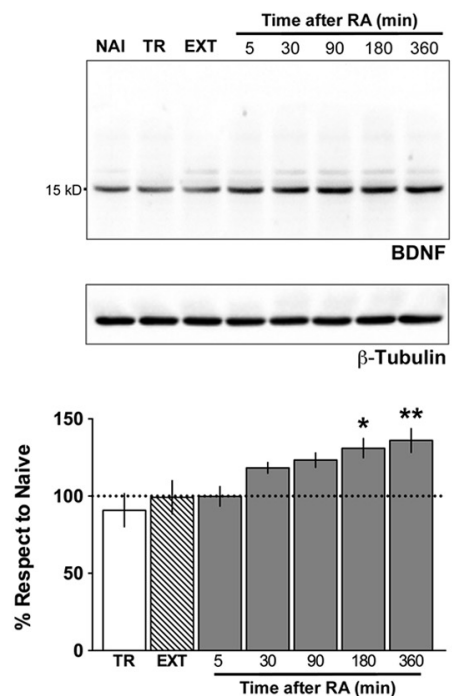
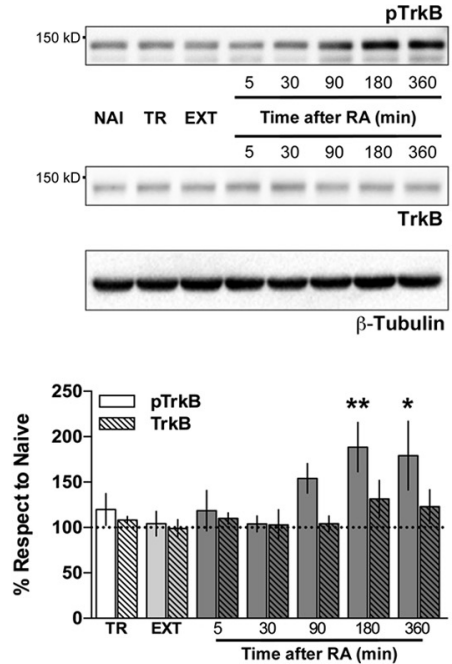

B

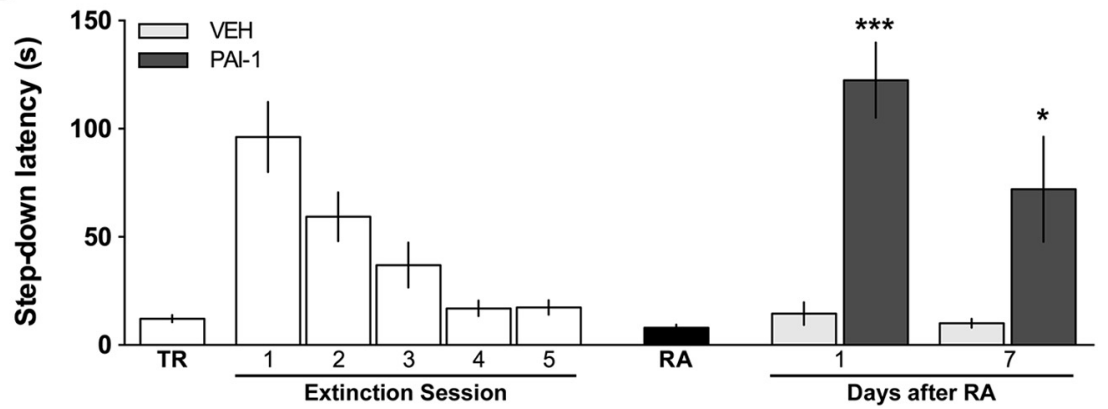

Figure 3. Reactivation of fear extinction memory increases BDNF signaling, and inhibition of BDNF maturation blocks fear extinction memory reconsolidation. $A$, Reactivation of fear

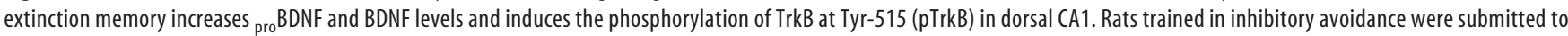
5 daily extinction sessions (first session $24 \mathrm{~h}$ after IA training). Twenty-four hours following the last extinction session, extinction memory was reactivated (RA), and the animals killed by decapitation at different times thereafter (5-360 min). The CA1 region of the dorsal hippocampus was dissected out, homogenized, and used to determine pro $^{B}$ BNF, BDNF, pTrkB, TrkB, and $\beta$-tubulin levels by immunoblotting. NAI, Naive animals; TR, animals trained in IA and killed $6 \mathrm{~d}$ later; EXT, animals trained in IA that were submitted to 5 daily extinction sessions (first session $1 \mathrm{~d}$ after training) and killed $24 \mathrm{~h}$ after the last one. Data are expressed as mean \pm SEM. $n=5$ animals per group. ${ }^{*} p<0.05$ (Dunnett's multiple-comparison test after repeated-measures ANOVA). ${ }^{* *} p<0.01$ (Dunnett's multiple-comparison test after repeated-measures ANOVA). ${ }^{* *} p<0.001$ (Dunnett's multiple-comparison test after repeatedmeasures ANOVA). $\boldsymbol{B}$, Postreactivation infusion of a BDNF maturation blocker hinders the persistence of the reactivated fear extinction trace. Animals were trained in IA (TR) and, beginning $24 \mathrm{~h}$ later, were submitted to one daily extinction session for $5 \mathrm{~d}$. Twenty-four hours after the last extinction session, extinction memory was reactivated (RA) and, immediately thereafter, the animals received bilateral intra-CA1 microinfusions of vehicle (VEH $=0.1 \%$ DMSO in saline) or of the BDNF maturation blocker PAI- 1 ( $50 \mathrm{ng} / \mathrm{side}$ ). Retention was analyzed 1 or $7 \mathrm{~d}$ later. Data are expressed as mean \pm SEM. $n=8$ or 9 animals per group. ${ }^{*} p<0.05$ (two-tailed Student's $t$ test). ${ }^{* * *} p<0.001$ (two-tailed Student's $t$ test).
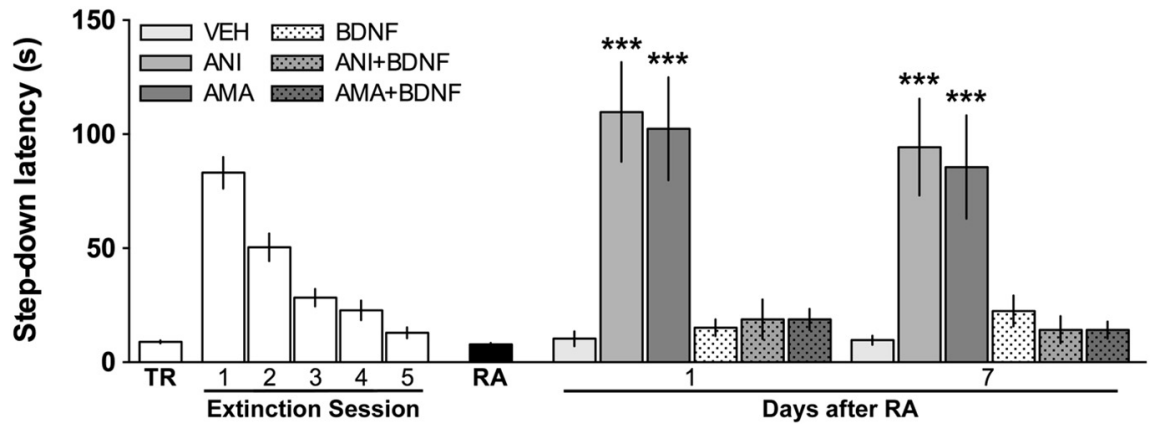

Figure 4. Intra-CA1 infusion of recombinant BDNF reverses the effect of ANI and AMA on extinction memory reconsolidation. Animals were trained in IA (TR) and, beginning $24 \mathrm{~h}$ later, were submitted to one daily extinction session for $5 \mathrm{~d}$. Twenty-four hours after the last extinction session, extinction memory was reactivated $(\mathrm{RA})$, and immediately thereafter the animals received bilateral intra-CA1 infusions of vehicle (VEH = 0.1\% DMSO in saline), ANI (160 $\mu \mathrm{g} / \mathrm{side}$ ), AMA (45 ng/side), BDNF (0.25 $\mu \mathrm{g} / \mathrm{side}$ ), ANI plus BDNF (ANI+BDNF), or AMA plus BDNF (AMA+BDNF). Retention was assessed 1 or $7 \mathrm{~d}$ after RA. Data are expressed as mean \pm SEM. $n=8-11$ per group. ${ }^{* * *} p<$ 0.001 in Dunnet's multiple-comparison test after ANOVA. pearance of avoidance (Fig. $3 B ; t_{(15)}=6.27$; $p<0.0001$ and $t_{(15)}=2.70 ; p=0.016$ for 1 and $7 \mathrm{~d}$ after reactivation, respectively). Importantly, coinfusion of recombinant $\operatorname{BDNF}(0.25 \mu \mathrm{g} / \mathrm{side})$ right after extinction memory reactivation impeded the recovery of the learned avoidance response induced by ANI and AMA, suggesting that BDNF is sufficient to restabilize the IA extinction memory trace after reactivation (Fig. 4).

\section{Discussion}

Most findings suggest that the persistent recollection of fearful and aversive experiences can be attenuated by enhancing extinction learning or by impairing memory reconsolidation. Our data indicate that the recurrence of learned fear can be controlled also by modulating BDNF 
signaling at the moment of extinction memory reactivation. This initiates a gene expression- and protein synthesis-dependent reconsolidation process that induces ${ }_{\text {pro }} \mathrm{BDNF}$, its conversion to mature BDNF, and the activation of TrkB in the dorsal hippocampus, and is totally hindered by blocking BDNF maturation or functionality. Furthermore, pharmacological activation of BDNF signaling immediately after extinction memory expression precludes the reemergence of fear caused by impairing extinction memory reconsolidation with inhibitors of mRNA and protein synthesis, suggesting that BDNF is not only necessary but also sufficient for maintaining the avoidance extinction memory trace after reactivation. Several plasticity phenomena susceptible to protein synthesis blockers, including conditioned taste aversion and spatial memory consolidation as well as synaptic potentiation (Pang et al., 2004; Martínez-Moreno et al., 2011; Ozawa et al., 2014), are restored by exogenous BDNF, perhaps through a mechanism involving inhibition of PKM $\zeta$ degradation (Mei et al., 2011). In this respect, it was demonstrated that BDNF is internalized promptly after exogenous application and becomes rapidly available for activity-dependent secretion, successfully replacing the new synthesis pathway (Santi et al., 2006). Our results showing that BDNFab, but not AMA or ANI, hinders extinction memory when given $6 \mathrm{~h}$ after reactivation indicate that gene expression and protein synthesis are dissociated from BDNF at this time point. On this matter, it was previously shown that BDNF regulates several plastic mechanisms in a protein-synthesisindependent manner (Panja and Bramham, 2014). For example, the rapid increase in synaptophysin and synaptobrevin levels induced by BDNF in hippocampal slices as well as the modulation of hippocampal high-frequency transmission produced by this neurotrophin are not prevented by protein synthesis inhibitors (Gottschalk et al., 1999; Tartaglia et al., 2001). The facilitatory role of BDNF in the acquisition of fear extinction is well documented (Andero and Ressler, 2012), and there seems to be a correlation between post-traumatic stress disorder risk and BDNF expression levels (Zhang et al., 2014). On the contrary, the involvement of BDNF in memory reconsolidation has seldom been demonstrated (Samartgis et al., 2012; Wang et al., 2012; Giachero et al., 2013). Indeed, it has been repeatedly suggested that BDNF actually participates in memory consolidation but not in reconsolidation (Lee et al., 2004; Lee and Hynds, 2013), which seems to contradict our results. However, it must be pointed out that our experiments do not entail the reactivation of a single memory trace, as is the case for almost all previous studies on the potential role of BDNF in memory reconsolidation but, instead, involve two conflicting well-consolidated memories competing for the control of behavior. Therefore, we think that, at least for the reconsolidation of extinction memory, it would be too simplistic to talk about BDNF as a "consolidation" or a "reconsolidation" protein. Instead, we prefer to think of BDNF as a key mediator of the physiological mechanisms controlling the persistent behavioral dominance of extinction memory after its reactivation. In any case, our results unravel a new role for BDNF and further demonstrate the existence of a hitherto unexplored window of opportunity for the treatment of anxiety disorders.

\section{References}

Andero R, Ressler KJ (2012) Fear extinction and BDNF: translating animal models of PTSD to the clinic. Genes Brain Behav 11:503-512. CrossRef Medline

Bekinschtein P, Cammarota M, Igaz LM, Bevilaqua LR, Izquierdo I, Medina JH (2007) Persistence of long-term memory storage requires a late protein synthesis- and BDNF-dependent phase in the hippocampus. Neuron 53:261-277. CrossRef Medline
Bekinschtein P, Cammarota M, Izquierdo I, Medina JH (2008) BDNF and memory formation and storage. Neuroscientist 14:147-156. CrossRef Medline

Bekinschtein P, Cammarota M, Katche C, Slipczuk L, Rossato JI, Goldin A, Izquierdo I, Medina JH (2008) BDNF is essential to promote persistence of long-term memory storage. Proc Natl Acad Sci U S A 105:2711-2716. CrossRef Medline

Giachero M, Bustos SG, Calfa G, Molina VA (2013) A BDNF sensitive mechanism is involved in the fear memory resulting from the interaction between stress and the retrieval of an established trace. Learn Mem 20: 245-255. CrossRef Medline

Gottschalk WA, Jiang H, Tartaglia N, Feng L, Figurov A, Lu B (1999) Signaling mechanisms mediating BDNF modulation of synaptic plasticity in the hippocampus. Learn Mem 6:243-256. CrossRef Medline

Heldt SA, Stanek L, Chhatwal JP, Ressler KJ (2007) Hippocampus-specific deletion of BDNF in adult mice impairs spatial memory and extinction of aversive memories. Mol Psychiatry 12:656-670. CrossRef Medline

Lee JL, Hynds RE (2013) Divergent cellular pathways of hippocampal memory consolidation and reconsolidation. Hippocampus 23:233-244. CrossRef Medline

Lee JL, Everitt BJ, Thomas KL (2004) Independent cellular processes for hippocampal memory consolidation and reconsolidation. Science 304: 839-843. CrossRef Medline

Martínez-Moreno A, Rodríguez-Durán LF, Escobar ML (2011) Late protein synthesis-dependent phases in CTA long-term memory: BDNF requirement. Front Behav Neurosci 5:61. CrossRef Medline

Mei F, Nagappan G, Ke Y, Sacktor TC, Lu B (2011) BDNF facilitates L-LTP maintenance in the absence of protein synthesis through PKM $\zeta$. PLoS One 6:e21568. CrossRef Medline

Ozawa T, Yamada K, Ichitani Y (2014) Hippocampal BDNF treatment facilitates consolidation of spatial memory in spontaneous place recognition in rats. Behav Brain Res 263:210-216. CrossRef Medline

Pang PT, Teng HK, Zaitsev E, Woo NT, Sakata K, Zhen S, Teng KK, Yung WH, Hempstead BL, Lu B (2004) Cleavage of proBDNF by tPA/plasmin is essential for long-term hippocampal plasticity. Science 306:487-491. CrossRef Medline

Panja D, Bramham CR (2014) BDNF mechanisms in late LTP formation: a synthesis and breakdown. Neuropharmacology 76:664-676. CrossRef Medline

Parsons RG, Ressler KJ (2013) Implications of memory modulation for post-traumatic stress and fear disorders. Nat Neurosci 16:146-153. CrossRef Medline

Peters J, Dieppa-Perea LM, Melendez LM, Quirk GJ (2010) Induction of fear extinction with hippocampal-infralimbic BDNF. Science 328:1288 1290. CrossRef Medline

Revest JM, Le Roux A, Roullot-Lacarrière V, Kaouane N, Vallée M, Kasanetz F, Rougé-Pont F, Tronche F, Desmedt A, Piazza PV (2014) BDNF-TrkB signaling through Erk1/2(MAPK) phosphorylation mediates the enhancement of fear memory induced by glucocorticoids. Mol Psychiatry 19:1001-1009. CrossRef Medline

Rosas-Vidal LE, Do-Monte FH, Sotres-Bayon F, Quirk GJ (2014) Hippocampal-prefrontal BDNF and memory for fear extinction. Neuropsychopharmacology 39:2161-2169. CrossRef Medline

Rossato JI, Bevilaqua LR, Izquierdo I, Medina JH, Cammarota M (2010) Retrieval induces reconsolidation of fear extinction memory. Proc Natl Acad Sci U S A 107:21801-21805. CrossRef Medline

Samartgis JR, Schachte L, Hazi A, Crowe SF (2012) Brain-derived neurotrophic factor facilitates memory consolidation and reconsolidation of a weak training stimulus in the day-old chick. Neurosci Lett 516:119-123. CrossRef Medline

Santi S, Cappello S, Riccio M, Bergami M, Aicardi G, Schenk U, Matteoli M, Canossa M (2006) Hippocampal neurons recycle BDNF for activity-dependent secretion and LTP maintenance. EMBO J 25:4372-4380. CrossRef Medline

Tartaglia N, Du J, Tyler WJ, Neale E, Pozzo-Miller L, Lu B (2001) Protein synthesis-dependent and -independent regulation of hippocampal synapses by brain-derived neurotrophic factor. J Biol Chem 276:3758537593. CrossRef Medline

Wang Y, Zhang TY, Xin J, Li T, Yu H, Li N, Chen ZY (2012) Differential involvement of brain-derived neurotrophic factor in reconsolidation and consolidation of conditioned taste aversion memory. PLoS One 7:e49942. CrossRef Medline

Zhang L, Benedek DM, Fullerton CS, Forsten RD, Naifeh JA, Li XX, Hu XZ, Li H, Jia M, Xing GQ, Benevides KN, Ursano RJ (2014) PTSD risk is associated with BDNF Val66Met and BDNF overexpression. Mol Psychiatry 19:8-10. CrossRef Medline 